\title{
THE USE OF PREPOSITIONS IN MEDICAL ENGLISH FOR ACADEMIC PURPOSES
}

\section{ОСОБЛИВОСТІ ВИКОРИСТАННЯ ПРИЙМЕННИКІВ У ПРОЦЕСІ ВИВЧЕННЯ ФАХОВОЇ АНГЛІЙСЬКОЇ МОВИ В МЕДИЧНИХ ВИШАХ}

\author{
Bieliaieva O.M. \\ orcid.org/0000-0001-9060-4753 \\ Candidate of Pedagogical Sciences, Associate Professor, \\ Head of the Department of Foreign Languages \\ with Latin and Medical Terminology \\ Ukrainian Medical Stomatological Academy
}

Lysanets Yu.V.,

orcid.org/0000-0003-0421-6362

Candidate of Philology, Associate Professor,

Associate Professor of the Department of Foreign Languages with Latin and Medical Terminology

Ukrainian Medical Stomatological Academy

Znamenska I.V. orcid.org/0000-0001-7091-6215

Candidate of Philology, Associate Professor, Associate Professor of the Department of Foreign Languages with Latin and Medical Terminology Ukrainian Medical Stomatological Academy

Rozhenko I.V. orcid.org/0000-0001-6656-5117

Lecturer in the Department of Foreign Languages with Latin and Medical Terminology Ukrainian Medical Stomatological Academy

Nikolaieva N.M. orcid.org/0000-0003-1976-9517 Lecturer in the Department of Foreign Languages with Latin and Medical Terminology

Ukrainian Medical Stomatological Academy

Due to the rapidly expanding use of English not only as a lingua franca but also as an essential communication tool in the global integration of scientific knowledge and international academic mobility, the English language training of researchers and teaching staff in medical universities has become a priority task in higher medical education. The article examines the features of mastering the use of prepositions while teaching the course in professional English for PhD students and academic staff at higher medical educational institutions. The authors created their own concept for the material which is presented in British English with appropriate explanations of US and globalised usage. The proposed approach has been tested in the development of the textbook "Medical English for Academic Purposes" (2018), which was written in the context of current trends in internationalised higher education, involving the training of specialists who will work in the modern English language educational and scientific environment. Each unit presents grammar and uses exercises and illustrative material to consolidate and activate the professional oral and written use of vocabulary and specialised terminology. The exercises approximate to tasks used in Cambridge English and IELTS International examinations (Writing and Speaking Modules). Extracts from original professional literature demonstrate the use of medical terminology. Theoretical aspects are introduced within the most common syntactic constructions in modern spoken and written scientific discourse. A series of training exercises has been presented, aimed at clarifying the peculiarities of using prepositions in modern English. The most commonly used prepositional phrases, their significance and contextual role in professional communication have been analyzed.

Key words: prepositions, English for Academic Purposes, academic staff, PhD students.

В умовах поглиблення інтеграційних процесів і поширення англійської мови не тільки як lingua franca, a і як важливого засобу передачі наукових знань, динамізації процесів академічної мобільності пріоритетним завданням вищої медичної освіти стає англомовна підготовка майбутніх науковців і викладацького складу медичних вишів. У статті досліджено особливості використання прийменників у процесі викладання курсу фрахової англійської мови для науково-педагогічних працівників і здобувачів ступеня доктора фрілософії у медичних вишах. Пропонований підхід спрямований на розвиток комунікативних навичок, необхідних для успішного міжнародного спілкування і співпраці, та апробований під час розроблення підручника "Medical English for Academic Purposes" (2018), який укладено з урахуванням сучасних тенденцій інтернаціоналізації вищої школи, що передбачає підготовку фахівців, які працювати- 
муть в англомовному просторі сучасної науки й освіти. Авторами вироблена власна концепція викладу навчального матеріалу. У підручнику запропоновано фррагменти текстів з оригінальних джерел сучасної англомовної фрахової літератури за тематичним принципом, що полегшує опрацювання галузевої термінології. Тексти супроводжуються розлогою мережею завдань, які закріплюють розмаїтий матеріал: граматику, загальновживану та загальнонаукову лексику, вузькофахові термінології. Представлено цикл навчальних вправ, що має на меті роз'яснення особливостей уживання прийменників у сучасній англійській мові. Проаналізовано найбільш уживані прийменникові звороти, їх значення та контекстуальну роль у фаховому мовленні. Теоретичний матеріал подано у вигляді схем і таблиць, які ефективно унаочнюють найуживаніші в сучасному науковому дискурсі граматичні категорії. Ілюстративний матеріал підібрано з метою поліпшення комунікативних навичок в усному й писемному мовленні.

Ключові слова: прийменники, фахова англійська мова, науково-педагогічні працівники, здобувачі ступеня доктора фрілософрії.

The adequate use of prepositions is one of the most challenging aspects in learning English as a second language. The major challenges in academic English vocabulary in terms of spelling and punctuation have already been discussed in our previous studies $[1 ; 2 ; 4 ; 5 ; 6 ; 7]$. The present paper focuses on the methods of mastering the use of prepositions and prepositional phrases by Ph.D. students, academic and clinical teachers of English-speaking medical students. The ability to use prepositions correctly is an essential prerequisite of a high quality medical discourse, which renders the present research relevant.

The results of the research have been integrated into the 1st edition of Medical English for Academic Purposes by Yu. Lysanets, O. Bieliaieva, M. Melaschenko (2018) [3]. Our approach focuses systematically on the use of prepositions with different parts of speech: nouns, adjectivs and verbs. The sample tasks given below demonstrate this strategy.

Sample tasks:

NOUNS AND PREPOSITIONS

Ex. 1. Many nouns have particular prepositions which normally follow them. Here are some common examples:

\begin{tabular}{|l|c|l|}
\hline \multicolumn{1}{|c|}{ Nouns } & Preposition & Translation \\
\hline 1. preference & for / over & \\
\hline 2. addiction & to & \\
\hline 3. search & for & \\
\hline 4. threat & to / from & \\
\hline 5. solution & to & \\
\hline 6. addiction & to & \\
\hline 7. damage & to / from & \\
\hline $\begin{array}{l}\text { 8. answer, response, } \\
\text { reaction }\end{array}$ & to / against & \\
\hline 9. alternative & to / for & \\
\hline $\begin{array}{l}\text { 10. investigation, } \\
\text { research }\end{array}$ & into & \\
\hline 11. advice & on / about & \\
\hline
\end{tabular}

\section{Ex. 2. Insert the prepositions:}

1. Addiction alcohol can result in numerous short and long term consequences.
2. Is there a less-expensive alternative this medication?

3. The damage the liver can come from viruses, such as the hepatitis $\mathrm{C}$ virus.

4. There is no solution this problem.

5. The response of the brain ___ external stimuli has been the subject of research for a long time.

6 . The psychiatrist offers advice mental health disorders.

7. Carcinomatous bleeding and perforating ulcers pose a threat patient's life.

8. The demand integrative approaches is high and neurocomputational models become recognised tools for tackling the complexity of epileptic phenomena.

9. We have a preference noninvasive treatments which minimise the risks of harmful side effects.

10. It seems likely that in vitro perfusion of glaucomatous eyes with enzymes may be useful in the search new methods of treatment for glaucoma

11. She did some research the causes of cancer.

Ex. 3. Translate the noun + preposition combinations:

\begin{tabular}{|l|c|l|}
\hline \multicolumn{1}{|c|}{ Noun } & Preposition & Translation \\
\hline 1) cure & for & \\
\hline 2) interest & in & \\
\hline 3) demand, request & for & \\
\hline 4) report & on & \\
\hline 5) responsibility & for & \\
\hline 6) access & to & \\
\hline 7) awareness & of & \\
\hline 8) contribution & to & \\
\hline 9) control & over & \\
\hline 10) resistance & to & \\
\hline 11) increase, rise & in/of & \\
\hline
\end{tabular}

Ex. 4. Complete the sentences with the noun + preposition combinations from Ex. 3. Use each combination only once:

1. Patient Portal is a secure online service providing global healthcare information. 
2. It was his molecular biology that won him the Nobel prize.

3. Patients who responded well to surgery felt some the pain.

4. This journal is designed for clinicians with a special anatomy.

5. In 2008, the committee published a allergy.

6. There is no known this disease.

7. Bacteria are evolving antibiotics much more quickly than global biomedical research efforts are delivering new drugs to market.

8. The integrative approaches is high and neurocomputing models become recognised tools for tackling the complexity of epileptic phenomena.

9. It is important to remember that the person administering the drug takes complications that arise from his or her actions.

10. Hospitals must increase patient treatment services

ADJECTIVES + PREPOSITIONS

Ex. 5. Translate the adjective + preposition combinations:

\begin{tabular}{|l|c|l|}
\hline \multicolumn{1}{|c|}{ Adjectives } & Preposition & Translation \\
\hline $\begin{array}{l}\text { 1. nice / kind / } \\
\text { stupid / silly / } \\
\text { intelligent / } \\
\text { clever / (im)polite / } \\
\text { rude / unreasonable }\end{array}$ & $\begin{array}{c}\text { of someone } \\
\text { (to do something) }\end{array}$ & \\
\hline $\begin{array}{l}\text { 2. nice / kind / good } \\
\text { / (im)polite / rude / } \\
\text { (un)pleasant / (un) } \\
\text { friendly / cruel }\end{array}$ & $\begin{array}{c}\text { to } \\
\text { (someone) }\end{array}$ & \\
\hline 3. bored / fed up & with & \\
\hline 4. keen & on & \\
\hline 5. short & of & \\
\hline 6. fond & of & \\
\hline 7. proud / ashamed & $\underline{\text { about something }}$ & \\
\hline 8. angry / furious & $\begin{array}{l}\text { with someone for } \\
\text { something }\end{array}$ & \\
\hline 9. pleased / satisfied & with & \\
/ disappointed & about something & \\
\hline 10. sorry & $\underline{\underline{\text { for doing }}}$ & \\
\cline { 2 - 3 } & something & \\
\hline & for someone & \\
\hline
\end{tabular}

Ex. 6. Complete the sentences with appropriate adjective + preposition combinations from Ex. 5:
1. I'm not what I did.
2. I feel your loss.

3. Why are you so it?

4. She is animals.

5. It was so me to go out without an umbrella.

6. I was the present you gave me. I'm

7. You get being so inattentive.

book all day long.

8. They were with reading the same to my party.

9. They have always been very me.

10. I was my examination results.

Ex. 7. Translate the adjective + preposition combinations:

\begin{tabular}{|l|c|c|}
\hline \multicolumn{1}{|c|}{ Adjective } & Preposition & Translation \\
\hline 1) crowded & with & \\
\hline 2) married & to & \\
\hline $\begin{array}{l}\text { 3) excited / worried / } \\
\text { upset }\end{array}$ & about & \\
\hline 4) good & at & \\
\hline 5) relevant & to & \\
\hline 6) different & from & \\
\hline 7) afraid & to & \\
\hline 8) similar & at / by & \\
\hline $\begin{array}{l}\text { 9) surprised / shocked / } \\
\text { amazed / astonished }\end{array}$ & for & \\
\hline 10) famous & of & \\
\hline 11) capable & with & \\
\hline $\begin{array}{l}\text { 12) satisfied / } \\
\text { disappointed / pleased }\end{array}$ & & \\
\hline
\end{tabular}

Ex. 8. Complete the sentences with appropriate adjective + preposition combinations from Ex. 7 . Use each combination only once:

1. Although some patients are anaesthesia, many patients prefer to have a higher dose of it.

2. This student is quite Anatomy.

3. Alexander Fleming is discovering Penicillin.

4. The patient is possible side effects of this medication.

5. HIV-1 infection is inducing a neurological disease that can cause dementia.

6. Domestic support is minimal, as the patient is a sedentary heavy smoker who has little interest in her own health problems.

7. The hall was conference participants.

8. The doctor was the drop in the blood pressure without the aid of medication. 
9. If there is a clinical trial available, the doctor will explain how that treatment plan is the standard one.

10. The students are their examination results.

11. The symptoms of endometriosis are other conditions such as pelvic infection and ovarian cysts.

12. The concept of treatment indication ranges from curative intent, palliative treatment and no treatment subgroups, which is practice of patients with hepatocellular carcinoma.

\section{VERBS + PREPOSITIONS}

Ex. 9. Translate the verb + preposition combinations:

\begin{tabular}{|l|c|l|}
\hline \multicolumn{1}{|c|}{ Verb } & Preposition & Translation \\
\hline 1. accuse smb & of smth & \\
\hline 2. belong & to & \\
\hline 3. care & for / about & \\
\hline 4. comment & of & \\
\hline 5. complain & from smb & \\
\hline 6. demand smth & to & \\
\hline 7. listen & in & \\
\hline 8. participate & with & \\
\hline 9. provide & to & \\
\hline 10. refer & on & \\
\hline 11. rely & to & \\
\hline 12. reply & from & \\
\hline 13. resign & from & \\
\hline 14. retire & of & \\
\hline 15. remind & & \\
\hline
\end{tabular}

Ex. 10. Complete the sentences with verb + preposition combinations from Ex. 9. Use each combination only once:

1. Relatives may the doctor misdiagnosing the patient, misleading them about the patient's progress, or mishandling the patient's treatment.

2. Management of newly diagnosed patients can well established protocols which allow to cure at least $75 \%$ of cases

3. Professor Knight the position of the Chairman of Medical Committee.

4. Our nurses always calls and queries in timely manner. patient's

5. The examiner did not these symptoms as to whether they were related to the patient's service-connected disability.

6. It is essential to the patient the importance of taking the medications as scheduled.

7. Sometimes the GP decides to the patient another doctor who specialises in the illness affecting this patient.
8. Treatment of this disease the patient accurate fulfiling of all the indications (dose and duration of the therapy).

9. The data patients. A patient needs to the health facility a consent to produce a copy of it.

10. Typically, when someone a staff position, the notification period is 7 to 14 days.

Ex. 11. Translate the verb + preposition combinations:

\begin{tabular}{|l|c|l|}
\hline \multicolumn{1}{|c|}{ Verb } & Preposition & Translation \\
\hline $\begin{array}{l}\text { 1) logos.lviv. } \\
\text { ua_OКтябp__2019. } \\
\text { pdf insist }\end{array}$ & on & \\
\hline 2) interfere & with / in & \\
\hline 3) mistake & for & \\
\hline 4) object & to & \\
\hline 5) prevent & from & \\
\hline 6) recover & from & \\
\hline 7) respond & to & \\
\hline 8) result & in & \\
\hline 9) search & for & \\
\hline 10) stand & for & \\
\hline 11) suffer & from & \\
\hline 12) wait & for & \\
\hline 13) warn & about/against & \\
\hline
\end{tabular}

Ex. 12. Complete the sentences using these verb + preposition combinations from Ex. 11 . Use the tense shown in brackets at the end of each sentence:

1. Removing the patient's impacted wisdom teeth the infection happening again (Present

\section{Perfect).}

2. COPD (chronic obstructive pulmonary disease) patients frequent exacerbations, often showing a typical seasonal pattern (Past Simple).

3. Most patients pneumonia and eventually have completely normal lungs (Present Perfect).

4. Symptoms of an underactive thyroid include feeling cold, inability to concentrate, being overweight, having a slow pulse, and several other symptoms which are easy the symptoms of flu; as a result many people do not recognise that they have an underactive thyroid gland for a long time (Infinitive).

5. Patients were particularly dissatisfied with information on how long the medicine would take to act, whether the medicine had any side effects, whether the medicine other medicines and what you should do if you forgot to take a dose (Past Simple). 
6. Muscle and adipose tissues insulin by accelerating glucose transport across the plasma membrane, and enhancing conversion to glycogen in muscle and to triacylglycerol in adipose tissue (Present Simple).

7. Medical scientists effective tools to diagnose the early onset of Parkinson's disease (Past Simple).

Thus, we believe that the suggested series of exercises will draw attention to the prominent role of prep- ositions in providing the cohesion and coherence of the English-language discourse, their significance and influence on the entire meaning of the text, as well as the problems related to incorrect use of prepositions and prepositional phrases. Adequate use of prepositions in medical English for academic purposes is an essential prerequisite of successful communication, intercultural reciprocal understanding and international cooperation in the context of rapid development of integration in Ukraine.

\title{
REFERENCES:
}

1. Бєляєва О.М. Функціонально-змістовні та функціонально-стильові характеристики наукових текстів. Інновації в освіті, науці та виробництві : матеріали шостої Всеукр. конф. (Полтава, 23-24 квіт. 2009 р.). Полтава, 2009. С. 108-110.

2. Bieliaieva O.M., Lysanets Yu.V., Znamenska I.V., Rozhenko I.V., Nikolaieva N.M. Terminological collocations in medical Latin and English: A comparative study. Wiadomości Lekarskie. 2017. № 70 (1). P. 139-143.

3. Lysanets Yu., Bieliaieva O., Melaschenko M. Medical English for Academic Purposes. Kyiv : AUS Medicine Publishing, 2018. 312 p.

4. Bieliaieva O., Lysanets Yu., Havrylieva K., Znamenska I., Rozhenko I., Nikolaieva N. Paronymy in the Sublanguage of Medicine (Linguistic and Linguo-Didactic Aspects). Georgian Medical News. 2017. № 10 (271). P. $144-149$.

5. Bieliaieva O., Synytsia V., Lysanets Yu. Pharmaceutical Terms with Onomastic Component: Quantitative, Structural and Lexico-Semantic Analysis. Wiadomości Lekarskie. 2018. Vol. 71. Nr. 1. Cz. II. P. $217-221$.

6. Lysanets Yu., Bieliaieva O., Nikolaieva N. Pseudo-Internationalisms in the Language of Medicine and Healthcare as a Challenge for Translation Studies. Актуальні проблеми романо-германської фрілології та прикладної лінгвістики : науковий журнал. Чернівці, 2017. Вип. 2 (15). С. 46-49.

7. Lysanets Yu., Bieliaieva O. The use of Latin terminology in medical case reports: Quantitative, structural, and thematic analysis. Journal of Medical Case Reports. 2018. 12:45. URL: https://jmedicalcasereports.biomedcentral.com/ articles/10.1186/s13256-018-1562-x.

\section{ЕЛЕКТРОННІ РЕСУРСИ ЯК ЗАСІБ ПОПОВНЕННЯ СЛОВНИКОВОГО ЗАПАСУ СТУДЕНТІВ}

\section{ELECTRONIC RESOURCES AS A WAY TO WIDEN STUDENTS' VOCABULARY}

\author{
Ворона T.O., \\ orcid.org/0000-0001-7177-8563 \\ викладач кафедри теорії та практики перекладу з німецької мови \\ Чорноморського національного університету імені Петра Могили
}

Розвиток новітніх технологій зумовлює зміну підходу до вивчення німецької мови. Якщо раніше студенти були змушені писати нові лексеми на спеціальних картках, заучувати, повторювати їх, то на сьогоднішній день існує велика кількість різноманітних ресурсів для ефективного та цікавого вивчення слів. Перевага таких ресурсів полягає у їх багатофункціональності: можна вчити слова з зображеннями, прослуховувати аудіо файли, виконувати різноманітні завдання і одразу ж отримувати результат у відсотковому співвідношенні.

Слід зазначити, що сучасний студент може уявити своє життя без друкованого словника або зошита, а без мобільного телефону - ні. Тому й основним технічним засобом для вивчення німецької мови необхідно обрати смартфон. Він вражає своїм функціоналом: можна дзвонити, знімати фоото та відео, друкувати тексти або диктувати їх і за допомогою спеціальних програм переводити у текстовий формат, мати доступ до інтернету (електронних словників, книг, робочих зошитів, сайтів для вивчення німецької мови).

Стаття присвячена електронним ресурсам для поповнення словникового запасу студентів. Зазначені роботи науковців, які присвятили свої праці застосуванням новітніх технологій для вивчення іноземних мов, а саме: П.Г. Аскоянц, Ю.А. Гапон, І.В. Крилов, С.Ю. Ніколаева, А.С. Нісімчук. 